The Migration of Musical Film 



\section{The Migration of Musical Film}

\section{From Ethnic Margins to American Mainstream}

DESIRÉE J. GARCIA

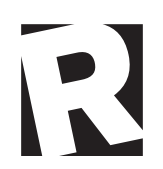

RUTGERS UNIVERSITY PRESS

NEW BRUNSWICK, NEW JERSEY, AND LONDON 


\section{LIBRARY OF CONGRESS CATALOGING-IN-PUBLICATION DATA}

Garcia, Desirée J., 1977-

The migration of musical film : from ethnic margins to American mainstream / Desirée J. Garcia.

pages $\mathrm{cm}$

Includes bibliographical references and index.

ISBN 978-0-8135-6865-2 (hardback)-ISBN 978-0-8135-6864-5 (pbk.)-ISBN 978-0-8135-6866-9 (e-book)

1. Musical films-United States-History and criticism. I. Title.

PN1995.9.M86G37 2014

$791.43^{\prime} 6-\mathrm{dc} 23$

A British Cataloging-in-Publication record for this book is available from the British Library.

Copyright @ 2014 by Desirée J. Garcia

All rights reserved

No part of this book may be reproduced or utilized in any form or by any means, electronic or mechanical, or by any information storage and retrieval system, without written permission from the publisher. Please contact Rutgers University Press, 106 Somerset Street, New Brunswick, NJ 08901. The only exception to this prohibition is "fair use" as defined by U.S. copyright law.

Visit our website: http://rutgerspress.rutgers.edu

Manufactured in the United States of America 
For my family 
